\title{
SPRAWOZDANIE Z DZIAŁALNOŚCI KOŁA NAUKOWEGO KATECHETYKÓW UKSW W ROKU AKADEMICKIM 2014/2015
}

Od początków swego istnienia, czyli od schyłku lat 60ych ubiegłego stulecia, Koło Naukowe Katechetyków UKSW znane było z dużej aktywności i podejmowania różnorodnych inicjatyw. Nie inaczej było w roku akademickim 2014/2015. Choć było to trudny czas, ze względu na malejąca liczba uczestników studiów doktoranckich z katechetyki, a także skądinąd cieszący fakt, iż wielu studentów V roku teologii rozpoczęło pracę na stanowisku nauczyciela religii w szkołach podstawowych lub gimnazjach. To jednak sprawiło, iż ci, którzy regularnie uczestniczyli w realizacji zadań statutowych Koła, mieli naprawdę wiele pracy. Nie lada wyzwaniem dla członków Koła z prezesem, p. mgr. Michałem Małkiem na czele - był rok akademicki 2013/2014, w czasie którego z powodzeniem podjęto wiele działań na rzecz pogłębiania refleksji katechetycznej oraz popularyzowania katechetyki w różnych kręgach.

Nowością w działalności Koła Naukowego Katechetyków UKSW było podkreślenie intencji służenia polskiej myśli katechetycznej w charakterze uniwersalnym. W tym celu podczas dorocznego spotkania Stowarzyszenia Katechetyków Polskich we wrześniu 2014 roku wystąpiono do członków Stowarzyszenia z propozycją nadania osobom zainteresowanym statusu „Sympatyka Koła”. Taką opcję przewidywał zmieniony na marcowym posiedzeniu Statut Koła Naukowego Katechetyków. Sympatycy Koła mieli być informowani o wszelkich planowanych inicjatywach, a jednocześnie mogli sami zwracać się z prośbą o podejmowanie tematów zgodnych z prowadzonymi przez siebie badaniami. Jako pierwsi Sympatykami Koła zostali p. dr Kamilla Frejusz, ks. dr hab. Marian Zając, ks. dr Waldemar Janiga, ks. dr Artur Filipiak, ks. dr Krzysztof Sosna oraz ks. dr Wojsław Czupryński ${ }^{1}$. Wymienione osoby z należytym wyprzedzeniem otrzymywały wiadomości o planowanych przez Koło działaniach. Działania te dotyczyły trzech obszarów - działalności

1 Koło Naukowe Katechetyków zaprasza wszystkich innych zainteresowanych uzyskaniem statusu „Sympatyka Koła” o zgłaszanie swej intencji do opiekuna Koła - p. dr A. Rayzacher-Majewskiej (a.rayzacher-majewska@uksw.edu.pl). Kontakt możliwy jest także przez stronę Koła na portalu społecznościowym Facebook: www.facebook.com/KoloNaukoweKatechetykowUKSW. 
naukowej, popularnonaukowej oraz zaangażowania w projekty na rzecz katechezy i katechetów.

\section{Działalność naukowa Koła Naukowego Katechetyków UKSW}

Koło Naukowe Katechetyków UKSW nie tylko aktywnie działa na rzecz naukowej refleksji nad katechezą organizując konferencje i sympozja, ale także na bieżąco uczestniczy w analogicznych wydarzeniach organizowanych przez inne jednostki. Z tej racji zdecydowano o wysłaniu przedstawiciela Koła na spotkanie klubu „Polonia Christiana” , które odbyło się dnia 11.X.2014. Temat spotkania „Ateizacja edukacji” był nie tylko ciekawy, ale także niezwykle aktualny. Autorem wystąpienia był p. dr Paweł Skrzydlewski², a Koło reprezentował na spotkaniu ks. mgr lic. Jacek Buta.

Innym katechetycznym wydarzeniem, na którym nie mogło zabraknąć przedstawicieli Koła, było XXXV Ogólnopolskie Sympozjum Katechetyczne w Lublinie, odbywające się w dniach 14-15 listopada 2014r. Spotkanie poświęcone było „Wychowaniu seksualnemu w katechezie”, a ciekawych wystąpień w omawianym temacie już od piątku słuchały p. Zofia Antonina Tranda oraz p. Anita Welenc, studentki specjalności nauczycielsko-katechetycznej na Wydziale Teologicznym UKSW. W drugim dniu sympozjum dołączyła do nich opiekun Koła - dr A. Rayzacher-Majewska. Wszystkie trzy panie przywiozły z Lublina książki pokonferencyjne, wiele ciekawych refleksji oraz dobrych wspomnień, którymi podzielono się z pozostałymi członkami na kolejnym spotkaniu Koła.

Tuż po lubelskim sympozjum Koło Naukowe Katechetyków było zaangażowane w organizację własnego przedsięwzięcia - konferencji szkoleniowej „Wspólna sprawa - możliwości współpracy katechety z rodzicami na rzecz formacji religijnej dziecka”. Członkowie Koła podjęli się tego tematu nawiązując do październikowego Synodu Biskupów o rodzinie. Na konferencję - stosownie do tematu - zaproszono zarówno katechetów uczących na różnych etapach edukacyjnych, jak i rodziców, a także studentów przygotowujących się do pracy katechetycznej oraz wszystkich innych zainteresowanych. Konferencję otwierał ks. prof. dr hab. Piotr Tomasik, dziekan Wydziału Teologicznego, witające serdecznie przybyłych gości - zarówno prelegentów, jak i słuchaczy. Podkreślił przy tym, jak ważnej tematyki dotknęli organizatorzy. Pierwszy z prelegentów - ks. dr Rafał Bednarczyk, w perspektywie historycznej przedstawił wzajemne relacje rodziców i katechetów, podkreślając specyfikę ich kontaktów przed rokiem 1990, zanim nauczanie religii powróciło do szkół. Zwrócił uwagę na fakt, iż wówczas wyraźnie była to podwójna odpowiedzialność, szczególnie zaś spoczywająca na rodzicach. Następnie głos zabrała dr

2 Artykuł jest dostępny w bieżącym numerze „Studiów Katechetycznych” w dziale „Varia”. 
Aneta Rayzacher-Majewska która w swym wystąpieniu zaprezentowała konkretne możliwości kontaktów i współpracy rodziców z nauczycielami. Jednocześnie ukazała zasadność tejże współpracy oraz potrzebę. Na temat współpracy katechetów z rodzicami mówił także ks. mgr Mateusz Bajak, choć tym razem przedstawił zagadnienie na gruncie parafii. W swym wystąpieniu zatytułowanym „Między próbą śpiewu a przymiarką" wskazał na możliwości wynikające ze wspólnych spotkań rodziców i katechetów, nie kryjąc przy tym zaniedbań w omawianym względzie. Kolejny prelegent nie ograniczał się do żadnego ze środowisk katechetycznych, bowiem podejmowany przez niego temat miał znaczenie uniwersalne i może mieć zastosowanie zarówno w szkolnym nauczaniu religii, jak i w katechezie parafialnej. Tematem tym była wspomagająca rola nowych mediów w komunikacji katechetów z rodzicami. Ostatnim gościem w części teoretycznej przewidziano p. mgr Katarzynę Browarską, psycholog, która miała przedstawić psychologiczne uwarunkowania skutecznej komunikacji, lecz choroba uniemożliwiła jej przybycie. Treści przygotowane przez p. Browarską przedstawiła p. dr A. Rayzacher-Majewska. Aby słuchacze mogli powracać w dogodnym momencie do każdego z wygłoszonych referatów, każdy otrzymał materiały konferencyjne zawierające skróty wszystkich wystąpień.

Po części teoretycznej i przerwie kawowej zaplanowano dyskusje w grupach. Organizatorzy zaproponowali następujące spotkania, podczas których uczestnicy mogli podzielić się doświadczeniami i zabrać głos: „Trudne sprawy” - katecheci wobec problemów z uczniem trudnym lub borykający się z trudnościami w kontakcie z rodzicem lub opiekunem; „Boże sprawy” - modele spotkań formacyjnych dla rodziców dzieci przygotowujących się do I Komunii świętej - dobre praktyki i trudności - wymiana doświadczeń; „Nasze sprawy” - wzajemne oczekiwania rodziców i katechetów w zakresie formacji religijnej dzieci. Ponieważ wielu przybyłych gości najchętniej uczestniczyłoby w każdej z proponowanych dyskusji, organizatorzy przychylili się do sugestii uczestników, by pozostać razem i wspólnie dyskutować na każdy z założonych tematów. Na szczególne podkreślenie zasługuje aktywność studentek UKSW, p. Ewy Popińskiej oraz p. Klaudii Naczke-Wójcik, które w omawianym roku akademickim rozpoczęły pracę na stanowisku nauczyciela religii w szkole i chętnie dzieliły się wrażeniami ze swego katechetycznego debiutu. Ich głos niewątpliwie utwierdzał pozostałych studentów w przekonaniu, iż warto zaangażować się na rzecz katechetycznej posługi Słowa, pokonując wszelkie obawy związane z tą posługą. Z kolei dla wszystkich katechetów uczestniczących w konferencji, wymiana myśli i dzielenie się dobrymi praktykami w zakresie kontaktów z rodzicami uczniów były cennym doświadczeniem, które niewątpliwie może przyczynić się do bardziej efektywnego działania. Zadowolenie ze spotkania uczestnicy najpełniej wyrazili pozostawiając swe adresy mailowe na liście osób zainteresowanych otrzymywaniem informacji o kolejnych tego typu inicjatywach podejmowanych przez Koło Naukowe Katechetyków UKSW. 
Kolejna wzmożona działalność naukowa Koła wiązała się z dorocznym międzyuczelnianym sympozjum studentów katechetyki KUL-UKSW, w którym czynny udział wzięli najbardziej aktywni członkowie Koła. Sympozjum odbyło się 22 kwietnia 2015r. w Lublinie. Tym razem omawiany temat brzmiał „Edukacja medialna katechetów". Zagadnienie już wcześniej było doskonale znane przedstawicielom obu uczelni, dlatego też wygłoszono wiele ciekawych referatów, a w panelu dyskusyjnym zarówno KUL, jak i UKSW reprezentowało pokaźne grono doktorantów i studentów ${ }^{3}$. Na wstępie wszystkich przybyłych serdecznie powitał prezes katechetyki KUL, ks. Rafał Czekalewski. W pierwszym wystąpieniu p. Michał Małek - absolwent Edukacji medialnej i dziennikarstwa UKSW - wyjaśnił podstawowe definicje związane z edukacją medialną i dziennikarstwem oraz nakreślił różnice między tymi dwoma pojęciami. Następnie p. Zofia Antonina Tranda (UKSW) omówiła obszary wspólne edukacji medialnej i szkolnego nauczania religii, uzasadniając potrzebę i wartość ich dialogu. W kolejnych wystąpieniach szczegółowo zaprezentowano podstawowe założenia i praktyczne rozwiązania dotyczące edukacji medialnej w katechezie dzieci i młodzieży. Na temat edukacji medialnej w katechezie dzieci przedszkolnych wypowiedziała się p. Magdalena Koper (KUL), ubogacając prelekcję doświadczeniami z własnej praktyki katechetycznej. W dalszej części p. Izabela Piątek-Belina (KUL) przedstawiła, jak powinna wyglądać edukacja medialna w katechezie dzieci, zaś p. Damian Belina (KUL) w analogiczny sposób odniósł się kolejnych etapów nauczania, prezentując edukację medialną w katechezie młodzieży. Jeszcze przed przerwą nie zabrakło wskazań dla edukacji medialnej w najznakomitszej formie katechezy, czyli katechezie dorosłych, czym zajął się ks. Mateusz Bajak (UKSW). Przerwa kawowa była okazją do wymiany myśli i skomentowania wystąpień w kuluarach, jak również służyła integracji obu środowisk akademickich. Dalsze punkty programu po przerwie stanowiły ciekawe połączenie nowoczesności z historią. Wpierw bowiem p. Mateusz Pisarek (KUL) zaprezentował słuchaczom, jaka jest rola edukacji cyfrowej $\mathrm{w}$ formacji katechetów, po czym głos przekazano Dodatkową atrakcją było wystąpienie ks. prof. dra hab. Stanisława Kulpaczyńskiego, który przedstawił szczegółowo „Rozwój badań empirycznych w KUL”. Uczestnicy mieli możliwość zapoznania się z bogatymi materiałem zdjęciowym zebranym przez ks. profesora, dokumentującym osiągnięcia KUL w zakresie badań. Dodatkową atrakcją było dla jednych - odnalezienie siebie na prezentowanych zdjęciach, dla innych zaś - wypatrzenie swych zacnych profesorów sprzed lat kilku lub kilkunastu. W tak radosnej atmosferze udano się na Mszę świętą, dziękując Panu Bogu za spotkanie i wszelkie łaski, których nie szczędzi katechetykom z dwóch znaczących ośrodków naukowych. Po Mszy świętej goście z UKSW - prezes Koła Naukowego Katechetyków - p. Michał Małek wraz z sekretarzem, p. Anitą Tyszkiewicz zabrali uczestników spotkania na

3 Program sympozjum oraz zdjęcia znajdują się na stronie Katechetyki KUL: www.katechetyka. eu/xli-miedzyuczelniane-sympozjum-katechetyki-kul-uksw,500.html 
kolejną podróż w czasie, tym razem z Kołem Naukowym Katechetyków UKSW, którego początki sięgają lat 60ych ubiegłego stulecia. Wyświetlona i omówiona przez nich prezentacja multimedialna nie pozostawiała wątpliwości co do tego, iż Koło Naukowe Katechetyków - tak, jak zapowiedziano w temacie - było i jest wizytówką katechetyki w ATK i UKSW. Ostatnim punktem spotkania był panel dyskusyjny, który prowadzili ks. mgr Rafał Czekalewski SAC oraz mgr Magdalena Koper, KUL. Wszyscy uczestnicy panelu mieli wpierw możliwość wyrażenia swojego zdania w omawianym temacie. Następnie wywiązała się między nimi żywa dyskusja, w trakcie której słuchacze mogli poznać wiele stanowisk i jeszcze więcej argumentów odnośnie do wyzwań edukacji medialnej nauczycieli. Nie zabrakło również pytań i głosów od publiczności, uważnie śledzącej przebieg dyskursu. Międzyuczelniane sympozja studentów katechetyki KUL-UKSW na dobre wpisały się w kalendarium obu uczelni, stając się swoistą tradycją. Zrozumiałe jest zatem, iż Koło Naukowe Katechetyków - nie tylko tę tradycję szanuje, ale także dokłada wszelkich starań, by z jak najlepszym efektem uczestniczyć w niej i nadawać jej kształtu.

W działalność naukową Koła Naukowego Katechetyków UKSW poza wspomnianymi konferencjami wpisują się comiesięczne spotkania, podczas których członkowie podejmowali refleksję nad istotnymi zagadnieniami oraz bieżącymi problemami z zakresu różnych form katechezy. Jeśli spotkanie następowało po innym ważnym $\mathrm{z}$ katechetycznego punktu widzenia wydarzeniu, to tematem było zagadnienie omawiane podczas tego wydarzenia. Tak działo się na dwóch pierwszych spotkaniach Koła w roku akademickim 2014/2015. W październiku, po zapoznaniu się z głównymi wątkami wystąpienia p. P. Skrzydlewskiego przytoczonymi przez ks. Jacka Butę, uczestnicy spotkania kontynuowali temat ateizacji w dzisiejszej przestrzeni edukacyjnej. Szczególnie wiele do powiedzenia mieli ci, którzy uczą religii w szkole, przez co mogą wyraźniej dostrzegać wszelkie mniej lub bardziej zawoalowane próby szerzenia ateizmu w szkołach. Z kolei na spotkaniu 26 listopada p. Zofia Antonina Tranda oraz p. Anita Welenc w skrócie przedstawiły zakres treści prezentowanych podczas sympozjum w Lublinie. „Wychowanie seksualne $w$ katechezie" również stanowiło jedną z kwestii dobrze znanych katechetom uczących w szkołach, zatem i w tym wypadku dyskutowano szerzej na dany temat. Grudniowe spotkanie Koła odbyło się 17 grudnia, a zagadnienie wiodące dotyczyło roli katechezy w przygotowaniu uczniów do udziału w roratach". Poprowadziły je pomysłodawczynie tematu, p. Zofia Antonina Tranda oraz p. Anita Welenc, a w dyskusję włączyli się wszyscy uczestnicy spotkania. W styczniu zrezygnowano z posiedzenia naukowego, bowiem zgodnie z wieloletnim zwyczajem spotkano się przy świątecznym stole, przedłużając radość z Narodzenia Pańskiego w gronie katechetyków UKSW. Kolejne spotkanie naukowe Koła odbyło się 18 lutego 2015r. Podniesiono na nim temat korelacji międzyprzedmiotowej, a każdy $\mathrm{z}$ uczestników zreferował odnaleziony uprzednio w dowolnym źródle artykuł. Po przypomnieniu teoretycznych aspektów korelacji, uczestnicy przeszli do dyskusji 
nad możliwościami i potrzebą korelacji religii z innymi przedmiotami szkolnymi. Jak zauważono, o ile korelacja z językiem polskim czy historią następuję często w dość naturalny sposób, o tyle zdecydowanie mniej popularne jest integrowanie treści z religii z treściami z przedmiotów ścisłych i przyrodniczych. $Z$ tej racji zdecydowano, by na kolejnym spotkaniu podjąć temat wzajemnych relacji wiary z naukami ścisłymi i przyrodniczymi. Stało się to 4 marca, a omówienie zagadnienia zbiegło się w czasie ze złożeniem przez członków Koła dwóch projektów dla katechetów nt. wiary i nauki, w odpowiedzi na konkurs grantowy ogłoszony przez ks. prof. Michała Hellera i prowadzone przez niego Centrum Kopernika Badań Interdyscyplinarnych. Wszystkie przeprowadzone spotkania Koła Naukowego Katechetyków UKSW potwierdziły, jak cenne jest podejmowanie refleksji naukowej nad katechezą w gronie studentów i doktorantów, szczególnie jeśli oni mają doświadczenie w pracy katechetycznej.

\section{Działalność popularnonaukowa}

Zgodnie ze Statutem Koła Naukowego Katechetyków UKSW, do celów Koła należy także działalność popularyzatorska. Z tej racji Koło bardzo chętnie włączało się w organizację lekcji pokazowych i spotkań dla różnych typów szkół, promując przy tej okazji katechetykę. Jeszcze przed rozpoczęciem roku akademickiego przeprowadzono lekcje religii w szkołach w Warszawie i okolicach w ramach Festiwalu Nauki. Tematy lekcji wpisywały się w tematykę Festiwalu, którą w roku 2014 był „człowiek, czas, przemijanie". Nowe horyzonty działania pojawiły się w październiku, gdy Koło Naukowe Katechetyków UKSW zostało zaproszone do włączenia się w organizację Festiwalu Kół Naukowych „Skołowany Weekend”. Imprezę planowano już po raz trzeci, a jej organizatorem było Chemiczne Koło Naukowe „Flogiston” Politechniki Warszawskiej. Koło Naukowe Katechetyków UKSW pozytywnie odpowiedziało na zaproszenie i rozpoczęło przygotowanie pokazów oraz starania o dofinansowanie inicjatywy przez Prorektora UKSW ds. studenckich i kształcenia.

W tym samym czasie podejmowano rozmowy z Orszakiem Trzech Króli na temat możliwości wzajemnej współpracy. Owocem rozmów było opracowywanie w grudniu 2014r. konspektów lekcji religii na rożne etapy edukacyjne z racji uroczystości Objawienia Pańskiego. Zajęli się tym członkowie Koła - p. Anna Kordulewska, p. Paweł Salach oraz prezes - p. Michał Małek. Inni przedstawiciele Koła nadal uczestniczyli w projekcie „Youcat na lekcjach religii”4, pisząc scenariusze lekcji dla szkół ponadgimnazjalnych z wykorzystaniem katechizmu młodych

\footnotetext{
4 O zaangażowaniu Koła Naukowego Katechetyków UKSW w tenże projekt pisała w sprawozdaniu koordynator projektu, p. Alekdandra Bałoniak: https://www.katecheta.pl/Projekty-edukacyjne/ Projekt-edukacyjny-Youcat-na-lekcjach-religii (20.05.2015).
} 
„Youcat”. Scenariusze ukazywały się na łamach miesięcznika „Katecheta”, a także zostały (lub zostaną) wydane w formie serii książek „Lekcja z Youcatem”.

Odkąd Koło Naukowe Katechetyków UKSW prowadzi swoją stronę na portalu społecznościowym Facebook, poszerzyło krąg odbiorców swej działalności o m. in. katechetów, którzy chcieliby nawiązać współpracę z uczelnią. W odpowiedzi na skierowaną tą drogą prośbę katechetki z Warszawy, p. Joanny Zając, 1 kwietnia 2015r. zorganizowano w UKSW spotkanie z uczniami jednej z warszawskich szkół podstawowych - członkami funkcjonującego w szkole koła religijnego. Uczniowie zwiedzili gmach uczelni, dowiedzieli się wiele o działaniu Koła - jego misji, zadaniach i sposobach realizacji, po czym sami mieli możliwość wykazania się rozległą wiedzą z zakresu religii poprzez zabawy i quizy. Wielką atrakcją było dla dzieci własnoręczne ozdabianie wydmuszek oraz malowanie gipsowych figurek wielkanocnych. Na zakończenie spotkania uczniowie otrzymali pamiątkowe dyplomy Małych Przyjaciół Koła Naukowego Katechetyków oraz gadżety z logo Koła długopisy i odblaski. Gośćmi ze szkoły zajmowali się p. Zofia Antonina Tranda, p. Michał Małek oraz p. Łukasz Traczyk.

Spotkanie z dziećmi z koła religijnego było próbą generalną przed większym wydarzeniem, czyli Festiwalem Kół Naukowych „Skołowany Weekend”. Pokazy Koła Naukowego Katechetyków - jednego z dwóch Kół na imprezie reprezentujących UKSW - miały odbyć się w niedzielę 26 kwietnia. Prezentacji dokonywali p. Anita Tyszkiewicz, p. Zofia Antonina Tranda oraz p. Michał Małek wraz z opiekunem, p. Anetą Rayzacher-Majewską. Pierwszy pokaz adresowany był do uczniów gimnazjum i nosił tytuł „Tam do kata... daj Youcata!”. Jego celem było promowanie katechizmu dla młodych wśród uczniów gimnazjum, poprzez zaprezentowanie katechizmu, zamysłu towarzyszącego opracowaniu publikacji, a także podkreślenia odmienności Youcata na tle dotychczasowych katechizmów i skojarzeń uczniów związanych z tym pojęciem. Kolejne wystąpienie adresowane było do uczniów ze szkoły podstawowej. Planowany tytuł brzmiał „Ojciec Wirgiliusz uczył dzieci swoje”, jednak w związku z nieobecnością tytułowego o. Wirgiliusza, konieczna była zmiana tej postaci i miejsce o. Wirgiliusza zajęła s. Mateusza, w którą wcieliła się p. Zofia Antonina Tranda. Dzieci stały się uczestnikami lekcji katechizmu prowadzonej w duchu dawnej epoki, w otoczeniu obrazów katechizmowych przepisywały piórem gęsim i atramentem fragment Katechizmu Rzymskiego o aniołach, których dotyczyła lekcja. Surowa prowadząca zadawała wiele pytań i dbała o dyscyplinę na zajęciach. Stosownie do tematu, uczestnicy malowali gipsowe aniołki, a na zakończenie odmówili po łacinie „Ave Maria”. Ostatni pokaz - przygotowany z myślą o uczniach ze szkół ponadgimnazjalnych - stanowił „Sąd nad podręcznikami do religii”. Zadbano o odpowiedni klimat, przywdziewając togi i wręczając zainteresowanym „akta sprawy”, czyli katalogi podręczników do religii lub kopie wybranych stron z podręczników. Choć oskarżyciele byli surowi i krytyczni wobec zaprezentowanego materiału dowodowego, obrona w niczym im nie ustępowała. Wprawdzie oceny podręczników dokonywały osoby nie mające do tego żadnego 
merytorycznego przygotowania, jednak ich opinie niewątpliwie mogłyby być cenne dla autorów czy recenzentów podręczników do religii, jako zdania wygłoszone przez odbiorców, a więc głównych zainteresowanych. Wyrok był skazujący, a obrona zapowiedziała odwołanie od niego. Wszystkie opisane pokazy były obserwowane przez organizatorów i zostały wysoko ocenione, w związku z czym zapowiedziano, iż Koło Naukowe Katechetyków UKSW może spodziewać się zaproszenia do udziału w kolejnej edycji festiwalu „Skołowany Weekend”. Niewątpliwie do atrakcyjności wystąpień przyczynili się dobroczyńcy Koła, jakimi byli: prorektor UKSW ds. studenckich i kształcenia ks. dr hab. Maciej Bała prof. UKSW przyznając dofinansowanie dla inicjatywy, a także: Wydawnictwo Św. Wojciech i Wydawnictwo Jedność, które zapewniły katalogi podręczników oraz Edycja św. Pawła, dzięki której uczestnicy pokazów otrzymali terminarze Youcat, egzemplarze rozważań liturgicznych „Od Słowa do życia”, broszury Biblii Jubileuszowej oraz foldery i zakładki. Z dofinansowania prorektora i środków własnych, Koło Naukowe Katechetyków przygotowało niezbędne wydruki i kopie materiałów katechetycznych, notesy UKSW oraz gadżety z logo Koła - długopisy, teczki, odblaski i... cukierki - krówki.

Działalność popularnonaukowa Koła Naukowego Katechetyków podejmowana w roku 2014/2015 przyniosła tak dobre owoce, iż podjęto już decyzję o kontynuowaniu jej w kolejnym roku. W związku z tym ponownie zgłoszono się do lekcji pokazowych i spotkania klubowego w ramach Festiwalu Nauki. Swój udział zadeklarowano również podczas Festiwali Nauki i Sztuki w Uniwersytecie Przyrodniczo-Humanistycznym w Siedlcach. Członkowie Koła pozostają przy tym otwarci na wszelką inną współpracę, której chęć można zgłaszać m.in. poprzez stronę na Facebooku.

\section{Realizacja projektów}

W ramach działalności naukowej podejmowanej przez Koło Naukowe Katechetyków UKSW w roku akademickim 2014/2015 należy podkreślić zupełnie nowy rodzaj aktywności, jakim jest realizacja projektów. Aktywność ta wiąże się z lekturą wywiadu z ks. prof. Michałem Hellerem, w którym laureat nagrody Templetona zachęca katechetów do zainteresowania uczniów wzajemnymi między wiarą i nauką ${ }^{5}$. W wywiadzie tym ks. M. Heller zaprosił do udziału w konkursie grantowym na projekt dotyczący wzajemnych relacji wiary i nauki. Do konkursu przystąpili prezes Koła - p. Michał Małek oraz członkowie: ks. Mateusz Bajak, p. Łukasz Traczyk i p. Daniel Kobrzycki, wraz z opiekunem naukowym. Opracowano dwa niezależne projekty - „Racjonalnie o wierze - cykl szkoleń dla katechetów uświadamiający potrzebę i możliwości pogłębiania wzajemnych relacji wiary i nauki” oraz „Na

\footnotetext{
5 http://www.niedziela.pl/artykul/13931/Ks-Heller-zacheca-katechetow-by (20.05.2015).
} 
skrzydłach wiary i rozumu - projekt programu szkolnych kół zainteresowań dla wszystkich etapów edukacyjnych". Oba wnioski wzbudziły zainteresowanie jury i zostały wysoko ocenione, w związku z czym podjęto decyzję o sfinansowaniu zarówno cyklu szkoleń, jak i utworzenia programów zajęć dodatkowych.

Pierwszy z projektów - „Racjonalnie o wierze” w sposób szczególny jest zaadresowany do katechetów Archidiecezji Warszawskiej oraz Diecezji Warszawsko-Praskiej, a także studentów Wydziału Teologicznego UKSW przygotowujących się do pracy katechetycznej. Dla popularyzacji projektu, utworzono stronę na portalu społecznościowym Facebook ${ }^{6}$, która już w pierwszym tygodniu działania została polubiona przez 100 osób, po czym liczba ta nieustannie wzrastała. Dla zbadania świadomości katechetów odnośnie do zgłębiania wiedzy szczególnie z zakresu nauk przyrodniczych i ścisłych, by móc następnie wykorzystywać tę wiedzę w pracy katechetycznej, sporządzono ankietę - zarówno w wersji papierowej, jak i on-line ${ }^{7}$. Nieustannie te $\dot{z}$ gromadzono literaturę dotyczącą zagadnień wiary i nauki, sporządzając przy tym bibliografię. Długo przygotowywanym wydarzeniem była konferencja naukowa „Racjonalnie o wierze”, odbywająca się w UKSW 13 czerwca 2015. Zgodnie z intencją organizatorów, do udziału zaproszono specjalistów z różnych dziedzin, którzy z własnej perspektywy wypowiedzieli się w kwestii wiary z perspektywy uprawianej nauki. Jako pierwszy wystąpił ks. dr hab. Tomasz Stępień, prof. UKSW, wprowadzając w zagadnienie nieco w perspektywie historycznej. Temat jego wystąpienia brzmiał „Wiara kontra nauka. O niektórych mitach związanych z usuwaniem światopoglądu religijnego przez naukowy”. Następnie p. dr n.med. Magdalena Szymańska - bioetyk i naprotechnolog z Instytutu Rodziny, zaprezentowała zagadnienie „Wiara w praktyce lekarskiej”. Dzieląc się nie tylko wiedzą, ale także bogatym doświadczeniem, zwróciła uwagę na to, iż na gruncie medycyny te dwie sfery są nie do rozdzielenia, jeśli za wartość nadrzędną obierze się dobro pacjenta i szczere pragnienie pomocy. Po przerwie kawowej, która rozbrzmiewała dyskusjami na temat wysłuchanych referatów, pojawili się kolejni prelegenci. Jednym z nich był dr Ryszard Kowalski z Uniwersytetu Przyrodniczo-Humanistycznego w Siedlcach. Podejmując temat „Katecheta w powszechnej edukacji przyrodniczej i środowiskowej społeczeństwa”, dość szczegółowo zaprezentował pilne potrzeby tejże edukacji, odwołując się przy tym do nauczania Jana Pawła II, a także aktualnych wskazań katechetycznych dokumentów programowych. Uczestnicy z zainteresowaniem śledzili przygotowaną prezentację multimedialną, a także z entuzjazmem przyjęli wiadomość o tym, iż prelegent udostępni ją wszystkim drogą mailową. Z uwagą wysłuchano także ostatniej prelekcji, której autorem był p. dr Franciszek Rakowski z Uniwersytetu Warszawskiego. Przedmiotem jego wystąpienia był „Umysł ludzki w perspektywie

\footnotetext{
6 https://www.facebook.com/pages/Racjonalnie-o-wierze/1384838275174051 (22.05.2015).

7 https://docs.google.com/forms/d/1KD6WbvVCnvc5UNvgoT5DDsFkBqbKmyv-y9c3xirjRVk/ viewform? $\mathrm{c}=0 \& \mathrm{w}=1$ (28.05.2015).
} 
wiary i nauki”. Choć nie zabrakło specjalistycznych pojęć i trudnych zwrotów charakterystycznych dla pracownika Interdyscyplinarnego Centrum Modelowania Matematycznego i Komputerowego, to sposób zaprezentowania zagadnienia czynił treść w pełni zrozumiałą. Istotnym walorem konferencji była możliwość dyskusji po każdym wystąpieniu, dzięki czemu uczestnicy mogli poszerzyć swą wiedzę o cenne argumenty z zakresu nauk ścisłych i przyrodniczych, co w przyszłości będą mogli wykorzystać w praktyce katechetycznej. Konferencja wpisywała się w inne działania podejmowane w ramach projektu - zebrano bazę e-mailową uczestników zainteresowanych udziałem $\mathrm{w}$ dalszych inicjatywach, rozdano konspekty lekcji religii skorelowane z przedmiotami ścisłymi i przyrodniczymi, a także zaproszono do zgłaszania się osób chętnych do przeprowadzenia lekcji otwartych na podstawie rozdanych konspektów. Innymi działaniami podjętymi przez osoby realizujące projekt „Racjonalnie o wierze” będzie autorstwo artykułów naukowych i popularnonaukowych, kontakt organizatorów z katechetami poprzez czat w wyznaczonych terminach, udział we wrześniowym Festiwalu Nauki oraz wprowadzenie do omówieni praktyk dla studentów Wydziału Teologicznego UKSW zagadnień związanych z wzajemnymi relacjami wiary i nauki.

Drugi projekt - „Na skrzydłach wiary i rozumu” w swym zasadniczym założeniu dotyczył opracowania czterech programów zajęć dodatkowych - kół zainteresowań, w ramach których uczniowie zgłębią zagadnienia ze styku wiary i nauki. $\mathrm{Z}$ realizacją projektu wiązał się m.in. panel dyskusyjny z udziałem studentów przygotowujących się do pracy katechetycznej oraz katechetów. Panel odbył się 21 maja 2015r. w UKSW. Specjalistami z rożnych dziedzin, wypowiadającymi się na temat religii i nauk przyrodniczych i ścisłych i ich możliwych powiązań byli: ks. dr Ryszard Sadowski sdb (Wydział Filozofii Chrześcijańskiej UKSW), mgr Grzegorz Diłanian (doradca metodyczny w zakresie nauczania religii) oraz mgr Łukasz Głaz (fizykochemik i nauczyciel chemii w XXXIII L.O im Mikołaja Kopernika w Warszawie). Spotkanie prowadzili p. Michał Małek oraz p. Daniel Kobrzycki. Na wstępie ks. Ryszard Sadowski wskazał na istotną rolę Kościoła w przeciwdziałaniu kryzysowi ekologicznemu, z czego katecheci powinni zdawać sobie sprawę. Wskazał on wprost konkretne tematy, które z powodzeniem można, a wręcz - trzeba włączać do nauczania religii (m.in. nakaz dbania o środowisko naturalne, korzyści zdrowotne płynące z zakazu stosowania hormonalnych środków antykoncepcyjnych). Następnie p. Łukasz Głaz zauważył, iż nauczanie fizyki również stwarza pewne możliwości pozwalające prowadzić uczniów do pytania o istnienie Boga (np. modele powstawania świata). Jako problematyczne wskazał zmiany w programie nauczania fizyki, które często ograniczają możliwości dialogu z religią, poprzez redukowanie tematów. Podkreślił też potrzebę wzajemnych kontaktów katechetów z innymi nauczycielami, bowiem ostatecznie to właśnie od ich postawy zależy, czy otworzą się na zdobycze nauk przyrodniczych i ścisłych, czy też pozostaną zamknięci we własnym kręgu. Z kolei p. Grzegorz Diłanian - nie kwestionując opinii wyrażonych przez swych poprzedników - dodał, iż poruszanie 
tych tematów z pewnością może zainteresować uczniów, pod warunkiem jednak, że będą oni mieć zapewnione swe potrzeby egzystencjalne. Odczuwany pod tym względem niedosyt czy brak mogą bowiem ograniczyć chęć przekraczania jednej dziedziny przez uczniów na rzecz poszerzania ich świadomości i wiedzy. Mówiąc zaś o konkretnych treściach i ich przekazie zauważył, iż nie ma pod tym względem jednej metody, po którą można sięgać, lecz katecheta powinien bacznie obserwować swą klasę i dopierać metody i środki stosownie do potrzeb i możliwości klasy również jeśli chodzi o zagadnienia z zakresu wiary i nauki. W dalszej części spotkania głos mogli zabrać wszyscy zainteresowani i wielu uczestników skorzystało z tej możliwości, a paneliści - stosownie do posiadanych kompetencji, starali się udzielić odpowiedzi na wszystkie kwestie. W ocenie uczestników panelu, spotkanie było niezwykle cenne, a studenci zadeklarowali, iż chętnie uczestniczyliby częściej w takiej formie, by wzmocnić swe kompetencje przyszłych katechetów. Ich oczekiwania będą spełnione jesienią, ponieważ w ramach projektu „Na skrzydłach wiary i rozumu” zostaną opracowane cztery programy zajęć dodatkowych prowadzonych w szkołach różnego typu przez katechetów i innych nauczycieli (np. w ramach tzw. godzin karcianych, czyli zajęć wynikających z art. 42 ust. 2 pkt. 2 ustawy Karta Nauczyciela). Na październik zaplanowano cztery panele dyskusyjne, stosownie do etapów edukacyjnych, w czasie których będzie można podzielić się wrażeniami z zajęć realizowanych według opracowanych programów.

Rok akademicki 2014/2015 był dla Koła Naukowego Katechetyków czasem niezwykle intensywnej działalności. Jednocześnie wszelkie podejmowane inicjatywy potwierdzały bogaty potencjał członków Koła i ich kreatywność, zaś nade wszystko - szczerą chęć zaangażowania na rzecz katechezy i naukowej refleksji nad nią. W następnym roku działalność ta będzie kontynuowana, a jednocześnie członkowie Koła nie zaprzestaną poszukiwania nowych obszarów i form działalności, poprzez którą będą mogli kontynuować rozbudzanie zainteresowań pracą naukową i badawczą, twórczą, samokształceniową i popularyzatorską w środowisku studenckim UKSW oraz współpracę z placówkami oświatowymi, badawczymi oraz użyteczności publicznej - tak, jak to zakłada Statut Koła. 